ISSN 2723-7583 (Online)

\title{
STRUKTUR KOMUNITAS TERIPANG (Holuthuroidea) PADA DAERAH PADANG LAMUN DENGAN KELAS PERSEN PENUTUPAN YANG BERBEDA DI PULAU SAPUDI KABUPATEN SUMENEP \\ COMMUNITY STRUCTURE OF TERIPANG (HOLOTHUROIDEA) IN SEAGRASS AREAS WITH DIFFERENT PERCENT CLOSURE CLASSES ON PULAU SAPUDI, SUMENEP REGENCY
}

\author{
Adi Wira Akrama ${ }^{1}$ dan Insafitri ${ }^{2}$ \\ ${ }^{1}$ Mahasiswa Program Studi IImu Kelautan, Jurusan Kelautan dan Perikanan Fakultas Pertanian, \\ Universitas Trunojoyo Madura \\ ${ }^{2}$ Program Studi IImu Kelautan, Jurusan Kelautan dan Perikanan Fakultas Pertanian, Universitas \\ Trunojoyo Madura
}

*Corresponding author e-mail: insafitri@yahoo.com

Submitted: 16 June 2020 / Revised: 23 June 2020 / Accepted: 23 June 2020

http://doi.org/ 10.21107/juvenil.v1i2.7572

\begin{abstract}
Sapudi Island is the second widest island after Kangean Island which is located between the islands east of Madura. This study aims to: (1) Know the quality of the waters; (2) Knowing the percent closure of seagrasses; and (3) Knowing the structure of sea cucumber communities at different seagrass cover percentages at the research station. The method used for the study is the quadratic transect of $5 \times 5 \mathrm{~m} 2$ for sea cucumber observation and $1 \times 1 \mathrm{~m} 2$ for seagrass observation. The results of this study are: (1) The quality of the waters at the research station is in accordance with the quality standards throughout the life of sea cucumbers; (2) Percent of seagrass closure at station 1 found the $3 r d$ and 4th seagrass closure class, while at station 2 found the 2nd and 3rd seagrass closure classes; and (3) the structure of sea cucumber community: the higher the seagrass closure class, the higher the density result, $\left(H^{\prime}\right)$ at station 1 is categorized as medium and at station 2 is classified as low category, (E) at station 1 and station 2 shows category height, (D) at station 1 and 2 indicate a low category.
\end{abstract}

Keywords: Community Structure of Sea Cucumber, Percent Closure of Different Seagrasses, Sapudi Island

\begin{abstract}
ABSTRAK
Pulau Sapudi merupakan kepulauan yang terluas kedua setelah Pulau Kangean yang terletak di antara pulau-pulau sebelah timur Madura. Penelitian ini bertujuan untuk: (1) Mengetahui kualitas perairan; (2) Mengetahui persen penutupan lamun; dan (3) Mengetahui struktur komunitas teripang pada persen penutupan lamun yang berbeda pada stasiun penelitian. Metode yang di gunakan untuk penelitian yaitu transek kuadrat $5 \times 5 \mathrm{~m}^{2}$ untuk pengamatan teripang dan $1 \times 1 \mathrm{~m}^{2}$ untuk pengamatan Lamun. Hasil dari penelitian ini yaitu: (1) Kualitas perairan pada stasiun penelitian sesuai dengan standar baku mutu suntuk kehidupan teripang; (2) Persen penutupan lamun pada stasiun 1 di temukan kelas penutupan lamun ke-3 dan 4, sedangkan pada stasiun 2 di temukan kelas penutupan lamun ke-2 dan 3; dan (3) struktur komunitas teripang: semakin tingggi kelas penutupan lamun, maka semakin tinggi juga hasil kepadatannya, $\left(H^{\prime}\right)$ pada stasiun 1 tergolong kategorinya sedang dan pada stasiun 2 tergolong kategori rendah, (E) pada stasiun 1 dan stasiun 2 menunjukkan kategori tinggi, (D) Pada stasiun 1 dan2 menunjukkan kategori rendah.
\end{abstract}

Kata Kunci: Struktur Komunitas Teripang, Persen Penutupan Lamun Berbeda, Pulau Sapudi

\section{PENDAHULUAN}

Struktur komunitas merupakan suatu kumpulan berbagai jenis organisme yang berinteraksi dalam suatu zonasi tertentu
(Muharram, 2006). Teripang merupakan hewan invertebrata yang memiliki tubuh yang lunak, berdaging dan berbentuk silindris memanjang seperti ketimun. Teripang memiliki 
Juvenil, 1(2), 180-188, (2020)

potensi ekonomi yang cukup tinggi dan banyak dimanfaatkan oleh masyarakat sebagai bahan makanan dengan kandungan gizi dan protein yang cukup tinggi. Teripang dapat ditemukan hampir diseluruh perairan pantai, mulai dari daerah pasang surut yang dangkal sampai perairan yang dalam (Martoyo et al., 2006).

Teripang memiliki peran penting dalam rantai makanan bagi berlangsungnya kehidupan berbagai jenis biota lain, dalam rantai makanan teripang sebagai penyumbang pakan berupa telur dan larva (Suryaningrum, 2008).

Teripang termasuk dalam filum Echinodermata yang merupakan salah satu biota yang berasosiasi dengan ekosistem padang lamun dan berperan dalam siklus rantai makanan di ekosistem tersebut. Tingginya tutupan vegetasi lamun di perairan memungkinkan kehadiran berbagai biota yang berasosiasi dengan ekosistem padang lamun termasuk teripang untuk mencari makan, tempat hidup, memijah dan tempat berlindung untuk menghindari predator (Supono dan Arbi, 2010).

Pulau Sapudi terletak di antara gugusan pulau-pulau kecil di sebelah timur pulau Madura. Secara administratif, pulau ini termasuk wilayah Kabupaten Sumenep, Madura, Jawa Timur. Pulau ini kaya akan biota laut salah satunya dari jenis Echinodermata seperti bulu babi, bintang laut, teripang dan lain-lain (Winda, 2013). Teripang telah dimanfaatkan oleh sebagian penduduk di Pulau Sapudi. Teripang biasanya diambil kemudian dijual kepengepul dan dikirim ke jawa untuk di olah. Penelitian tentang teripang ini belum pernah dilakukan di stasiun tersebut. Sehubungan dengan masih kurangnya informasi mengenai struktur komunitas teripang di Pulau Madura khususnya di Pulau Sapudi, maka penelitian di bidang tersebut perlu dilakukan terhadap struktur komunitas teripangyang dilakukan pada habitat lamun Pulau Sapudi, Kabupaten Sumenep, Madura.

\section{MATERI DAN METODE Waktu dan Tempat}

Penelitian dilakukan pada bulan November 2018 di perairan Pulau Sapudi, Kabupaten Sumenep Provinsi Jawa Timur. Sedangkan untuk analisa sedimen dilakukan pada tanggal bulan Januari 2019 di laboratorium oseanografi ilmu kelautan Universitas Trunojoyo Madura. Pada pengamatan saat di lapang dilakukan pada 2 stasiun dengan setiap stasiun terdapat tiga titik yang dilakukan mulai ditemukannya lamun sampai tidak ditemukan lamun. Stasiun 1 di Desa Pancor dan stasiun 2 di Desa Prambanan. Pengambilan dua stasiun tersebut di akibatkan ada perbedaan antar stasiun yaitu pada stasiun 1 tidak ada aktifitas pengerukan pasir sedangkan pada stasiun 2 ada aktifitas pengerukan pasir untuk di jual menjadi bahan bangunan.

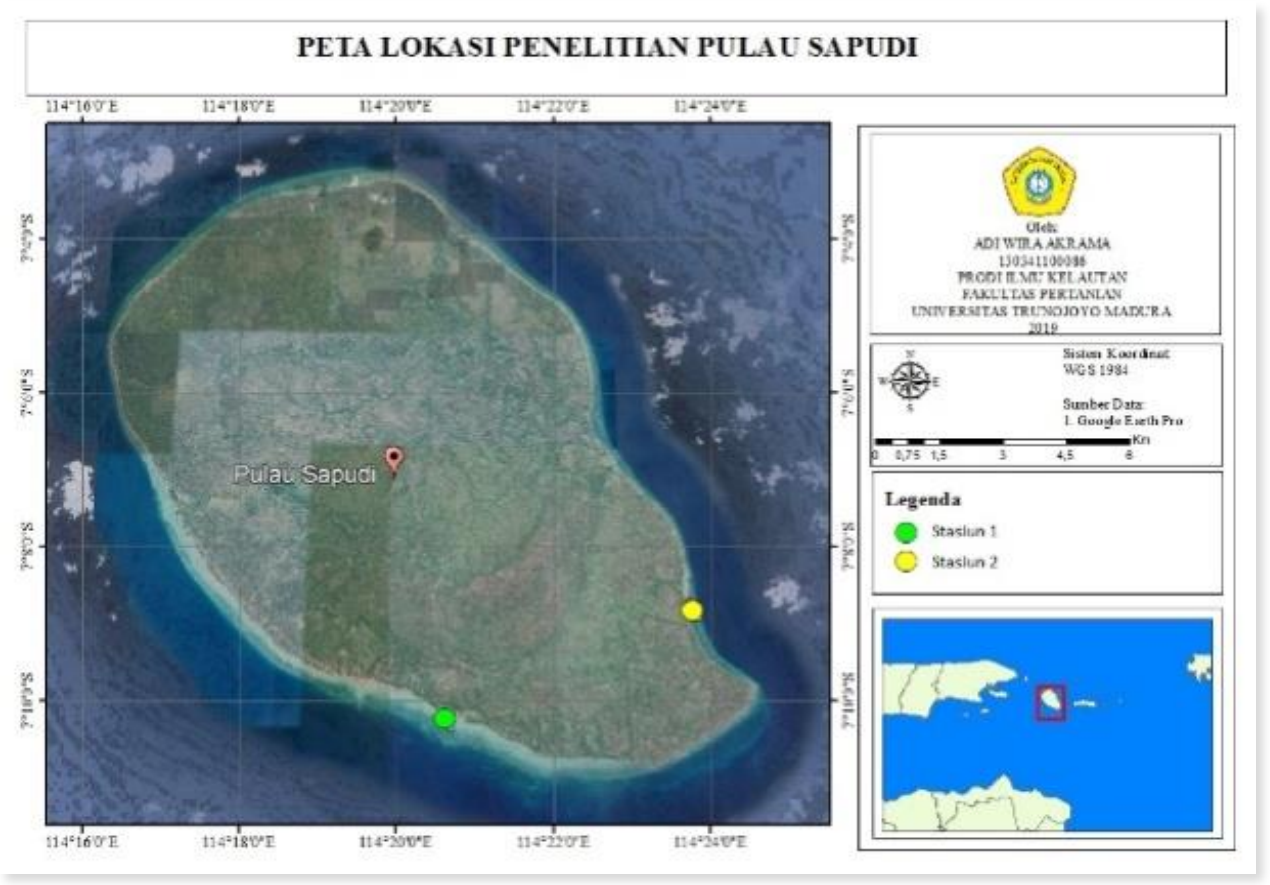

Gambar 1. Lokasi Penelitian 
Akrama dan Insafitri, Struktur Komunitas Teripang

\begin{tabular}{llrr}
\hline Peletakan & transek & dilakukan & secara \\
bersamaan & dalam & menentukan & struktur
\end{tabular}

komunitas teripang dan kelas persen penutupan lamun. Transek teripang menggunakan transek kuadrat dengan ukuran transek $5 \times 5 \mathrm{~m}^{2}$ sedangkan untuk transek persen penutupan lamun juga menggunakan

\section{Alat dan Bahan Penelitian}

Alat dan bahan yang digunakan dalam penelitian ini meliputi alat kualitas air yaitu DO meter, Refraktometer, Ph meter GPS, Termometer, Secchidisk dan bola duga. Adapun alat yang digunakan dalam pengamatan teripang yaitu Transek kuadrat, sedangkan bahan yang digunakan meliputi sampel air dan substrat serta sampel teripang dan lamun.

\section{Pengamatan Teripang dan Lamun}

Pada pengamatan saat di lapang dilakukan pada 2 stasiun dengan setiap stasiun terdapat tiga titik yang dilakukan mulai ditemukannya lamun sampai tidak ditemukan lamun. Stasiun 1 di Desa Pancor dan stasiun 2 di Desa Prambanan. Pengambilan dua stasiun tersebut di akibatkan ada perbedaan antar stasiun yaitu pada stasiun 1 tidak ada aktifitas pengerukan pasir sedangkan pada stasiun 2 ada aktifitas pengerukan pasir untuk di jual menjadi bahan bangunan.

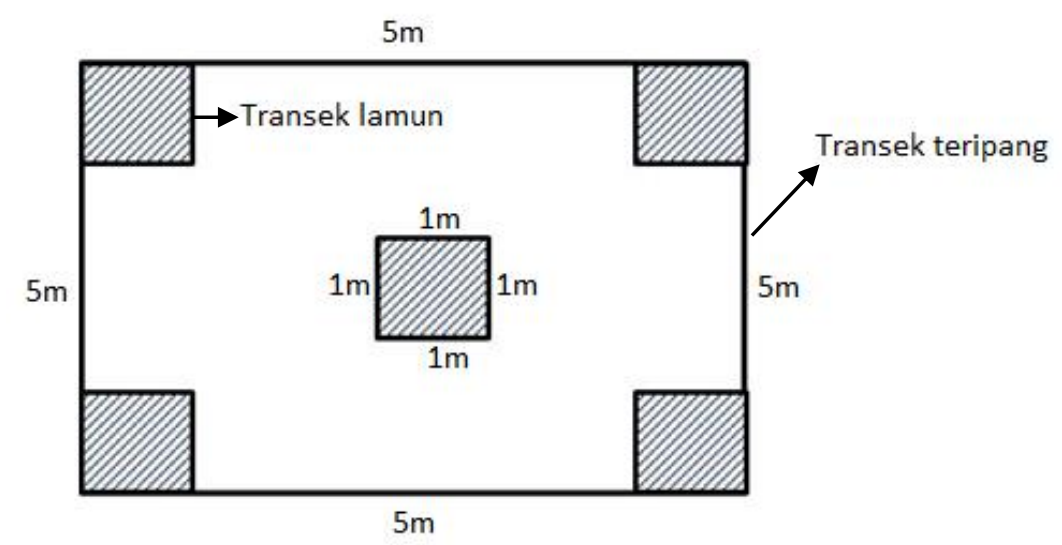

Gambar 2. Transek yang di arsir untuk pengamatan lamun dan yang tidak di arsir untuk teripang (tanpa skala)

Analisa Data

\section{Kepadatan Teripang}

Kepadatan $=\frac{\text { Jumlah Individu Suatu Spesies }}{\text { Luas kuadran }}$

Indeks Keanekaragaman Teripang

$$
H^{\prime}=-\sum P i L n P i \text { dimana } P i=\frac{n i}{N}
$$

ransek kuadrat dengan ukuran transek $1 \times 1$

$\mathrm{m}^{2}$ dengan lima kali pengulangan dalam setiap 1 kali transek teripang. Setelah pengamatan diketahui bahwa pada stasiun 1 dan stasiun 2 ditemukan lamun jenis Thalssia hemprichi, Enhalus acroides, Halophila ovalis, dan Syringodium isoetifolium.

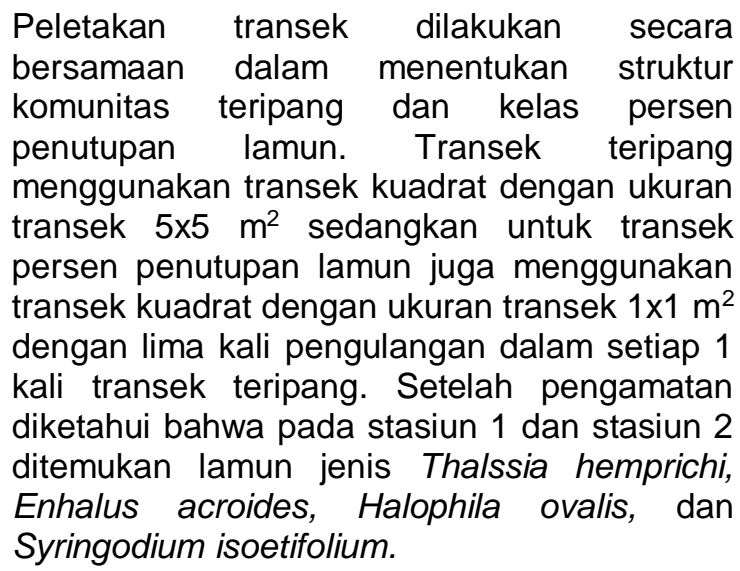

Gambar di bawah dapat dilihat gambar transek yang di gunakan saat penelitian di lapang untuk kotak yang di arsir untuk pengamatan lamun dan yang tidak di arsir untuk pengamatan teripang. Gambar plot atau transek yang digunakan dapat dilihat pada Gambar 2. 
Juvenil, 1(2), 180-188, (2020)

Indeks Keseragaman Teripang

$$
E=\frac{\mathrm{H}^{\prime}}{\mathrm{H}^{\prime} \text { maks }}
$$

$\mathrm{E}=\quad$ indeks keseragaman jenis

$\mathrm{H}^{\prime}=$ indeks keseragaman

$\mathrm{H}^{\prime}$ maks $=$ indeks keragaman maksimum

\section{Indeks Dominasi Teripang}

$$
D=\sum_{I=1}^{S}\left(\frac{N i}{N}\right)^{2}
$$

$\begin{array}{ll}\mathrm{D}= & \text { indeks dominasi Simpson } \\ \mathrm{Ni}= & \text { jumlah individu jenis ke- } \mathrm{i} \\ \mathrm{N}= & \text { jumlah total induvidu seluruh } \\ \mathrm{S}= & \text { jenis } \\ & \text { Jumlah jenis }\end{array}$

\section{Persen penutupan lamun}

$$
C i=\frac{\sum(\mathrm{Mixfi})}{\sum f}
$$

\begin{tabular}{|c|c|c|c|c|c|c|}
\hline \multirow{3}{*}{ No } & \multirow{3}{*}{ Family } & \multirow{3}{*}{ Jenis Teripang } & \multicolumn{4}{|c|}{ Kepadatan (ind/transek/m²) } \\
\hline & & & \multicolumn{2}{|c|}{ Stasiun 1} & \multicolumn{2}{|l|}{ Stasiun 2} \\
\hline & & & Kelas 3 & Kelas 4 & Kelas 2 & Kelas 3 \\
\hline 1 & Holothuria & H. fuscocinerea & 0,3 & 0,3 & - & - \\
\hline 2 & & H. hilla & 1,3 & 2,5 & - & - \\
\hline 3 & & H. leucospilota & 0,2 & - & - & - \\
\hline 4 & & H. atra & 0.9 & - & 0,06 & 0,3 \\
\hline 5 & & H. pardalis & 0,1 & 0,2 & - & - \\
\hline 6 & Thelenota & T. anax & 0,09 & 0,2 & - & - \\
\hline 7 & Synaptidae & Synapta maculata & 2 & 3,7 & 0,1 & 0,4 \\
\hline
\end{tabular}

Tabel 1. Kepadatan jenis teripang (ind/transek $/ \mathrm{m}^{2}$ ) pada stasiun penelitian

(-) Tidak di temukan

Jenis teripang yang di temukan dengan kepadatan terendah pada satsiun 1 dengan kelas persen penutupan ke-3 yaitu Thelonata anax dan pada kelas ke-4 yaitu $H$. pardalis, sedangkan pada stasiun 2 dengan persen penutupan ke-2 dan ke-3 yaitu $H$. atra, karena
$\mathrm{Ci}=$ Persentase penutupan jenis lamun ke- $\mathrm{i}$

$\mathrm{Mi}=$ Persentase titik tengah dari kelas kehadiran jenis lamun ke-i

$\mathrm{F}=\quad$ Banyaknya subpetak dimana kelas kehadiran jenis lamun ke-i

$\Sigma f=\quad$ Jumlah seluruh kehadiran dari lamun ke-i

\section{Kepadatan Teripang}

Berdasarkan hasil penelitian yang telah dilakukan pada dua stasiun diperoleh hasil kepadatan dan di temukannya jenis teripang yang berbeda jauh antara kedua stasiun tersebut. Stasiun 1 kelas persen penutupan ke-3 di temukan 7 jenis teripang yaitu $H$. fuscoinerea, $H$. hilla, $H$. leucospilota, $H$. atra, $H$. pardalis, $T$. anax, dan Synapta maculate, sedangkan pada stasiun 1 dengan kelas persen penutupan ke-4 di temukan 5 jenis teripang yaitu $H$. fuscoinerea, $H$. hilla, $H$. pardalis, $T$. anax, dan Synapta maculata. Stasiun 2 dengan kelas persen penutupan ke2 dan ke-3 hanya di temukan 2 jenis teripang

\begin{tabular}{|c|c|}
\hline Stasiun & $\begin{array}{l}\text { Kepadatan Total } \\
\text { (ind/transek } / \mathrm{m}^{2} \text { ) }\end{array}$ \\
\hline 3 & 5,1 \\
\hline 4 & 7,1 \\
\hline 2 & 0,2 \\
\hline 3 & 0,7 \\
\hline $\begin{array}{l}\text { Berdasarkan hasil perhitungan kepadatan di } \\
\text { atas pada stasiun } 1 \text { dengan kelas persen } \\
\text { penutupan lamun ke-3 diperoleh hasil } \\
\text { kepadatan teripang } \quad \text { sebesar } r 5,1 \\
\text { ind/transek/m2 dan pada kelas persen }\end{array}$ & $\begin{array}{l}\text { penutupan lamun ke-4 sebesar } 7,1 \\
\text { ind/transek/m2, sedangkan pada stasiun } 2 \\
\text { dengan kelas persen penutupan lamun ke-2 } \\
\text { diperoleh kepadatan teripang sebesar } 0,2 \\
\text { ind/transek/m2 dan pada kelas persen }\end{array}$ \\
\hline
\end{tabular}
yaitu $H$. atra dan Synapta maculata (Tabel 1.).

Tabel 2. Kepadatan total teripang (ind/transek $/ \mathrm{m}^{2}$ ) pada stasiun penelitian 
Akrama dan Insafitri, Struktur Komunitas Teripang (Holuthuroidea)

penutupan lamun ke-3 diperoleh kepadatan

teripang sebesar $0,7 \mathrm{ind} /$ transek/m2.

Hasil di atas apabila di lihat dari stasiun yang sama dengan kelas penutpan lamun berbeda menunjukkan bahwa pada stasiun 1 dengan kelas persen penutupan lamun ke-4 kepadatannya lebih tinggi di bandingkan kelas ke-3, sedangkan pada stasiun 2 dengan kelas persen penutupan lamun kelas ke-3 lebih tinggi di bandingkan kelas ke-2. Jika hasil di atas dilihat dari sudut pandang yang berbeda yaitu kelas penutupan lamunnya sama akan tetapi bebeda pada stasiunnya, hasil di atas kelas penutupan lamunnya yang sama adalah kelas ke-3 yang menunjukkan bahwa hasil persen penutupan lamun kelas ke-3 pada stasiun 1 lebih tinggi jika dibandingkan dengan kelas-3 yang ada pada stasiun 2. Hal tersebut menunjukkan bahwa kepadatan teripang dipengaruhi oleh kelas persen peutupan lamun.

Semakin tinggi persen penutupan lamun akan semakin tinggi pula kepadatan teripang yang ditemukan pada stasiun tersebut begitupun sebaliknya semakin rendah persen kelas penutupan lamun semakin rendah juga kepadatan teripangnya. Oktamalia et al., (2016) menyatakan bahwa rendahnya kepadatan teripang diakibatkan adanya penangkapan secara terus menerus yang dilakukan oleh nelayan. Selain itu kepadatan teripang juga dipengaruhi stasiun yaitu pada kelas yang sama, kepadatan teripang pada stasiun 1 lebih tinggi dari pada stasiun 2.

Nilai kepadatan yang diperoleh kemudian dilakukan pengujian hipotesis dengan SPSS untuk membandingkan kepadatan teripang stasiun 1 dan stasiun 2. Uji statistik yang dilakukan terlebih dahulu dengan menggunakan uji normalitas. Hasil uji Tabel 3. Indeks Keanekaragaman Teripang pada Tiap Stasiun Pengamatan normalitas perhitugan signifikan: Test Kolmogrov - Smirnov $=0,000<0,05$ (data nilai tidak berdistribusi normal) dan hasil Shapiro - Wilk $=0,000<0,05$ (data nilai tidak berdistribusi normal). Karena data tidak berdistribusi normal maka pengujian yang di gunakan untuk pengambilan hipotesis yaitu menggunakan perhitungan non parametrik yaitu dengan uji Mann-Whitney sebagai pengganti Uji T. Pengambilan keputusan uji Mann-Whitney yaitu jika nilai Asymp.Sig < 0,05 maka hipotesis ditolak sedangkan jika Asymp. Sig > 0,05 maka hipotesis diterima. Berdasarkan output uji stasistik diketahui Asymp.Sig (2-tailed) bernilai $0,000<0,05$, maka dapat disimpulkan bahwa hipotesis ditolak artinya ada perbedaan antara hasil kepadatan stasiun 1 dan stasiun 2, yang artinya ada pengaruh yang membedakan hasil stasiun 1 dan 2.

\section{Keanaekaragaman Teripang}

Hasil perhitungan indeks keanekaragaman teripang dapat dilihat pada Tabel 4.3 nilai keanekaragaman $\left(H^{\prime}\right)$ pada perairan pulau Sapudi Kecamatan Gayam Kabupaten Sumenep pada stasiun 1 dengan kelas persen penutupan ke-3 dan ke-4 memiliki tingkat keanekaragaman sedang dengan nilai indeks keanekaragaman pada kelas ke-3 sebesar 1,518 dan kelas ke-4 sebesar 1,059. Pada stasiun 2 dengan persen penutupan ke-2 sebesar 0,636 dan ke-3 sebesar 0,689 termasuk dalam kategori memiliki tingkat keanekaragaman rendah dengan nilai indeks keanekaragaman pada kelas ke-2 sebesar dan kelas ke-3 sebesar 0,685. Kriteria tersebut di nyatakan pada stasiun 1 dengan kelas persen penutupan ke-3 dan ke-4 termasuk kriteria sedang dan pada stasiun 2 kelas ke-2 dan ke-3 termasuk dalam kriteria rendah, hal tersebut di lihat berdasarkan kriteria di bawah.

\begin{tabular}{llll}
\hline Stasiun & Kelas & Keanekaragaman $\left(\mathrm{H}^{\prime}\right)$ & Keterangan \\
\hline 1 & 3 & 1,518 & Sedang \\
\hline & 4 & 1,059 & Sedang \\
\hline & 2 & 0,636 & Rendah \\
\hline
\end{tabular}

Keterangan:

\begin{tabular}{ll}
\hline Nilai indeks keanekaragaman $\left(H^{\prime}\right)$ & Kriteria \\
\hline$H^{\prime} \leq 1$ & $\begin{array}{l}\text { Keanekaragaman rendah, produktivitas sangat rendah sebagai } \\
\text { indikasi adanya tekanan yang berat dan ekosistem tidak stabil }\end{array}$ \\
$1 \leq H^{\prime} \leq 3$ & $\begin{array}{l}\text { Keanekaragaman sedang, tekanan ekologis sedang. } \\
H^{\prime} \geq 3\end{array}$ \\
& $\begin{array}{l}\text { Keanekargaman tinggi, stabilitas ekosistem mantap, produktivitas } \\
\text { tinggi, tahan terhadap tekanan ekologis. }\end{array}$ \\
\hline
\end{tabular}


Juvenil, 1(2), 180-188, (2020)

Nilai keanekaragaman yang diperoleh kemudian dilakukan pengujian hipotesis dengan SPSS untuk membandingkan keanekaragaman teripang stasiun 1 dan stasiun 2. Uji statistik yang dilakukan terlebih dahulu dengan menggunakan uji normalitas. Hasil uji normalitas perhitugan signifikan: Test Kolmogrov - Smirnov $=0,000<0,05$ (data nilai tidak berdistribusi normal) dan hasil Shapiro - Wilk $=0,001<0,05$ (data nilai tidak berdistribusi normal). Karena data tidak berdistribusi normal maka pengujian yang di gunakan untuk pengambilan hipotesis yaitu menggunakan perhitungan non parametrik yaitu dengan uji Mann-Whitney sebagai pengganti Uji T. Pengambilan keputusan uji Mann-Whitney yaitu jika nilai Asymp.Sig < 0,05 maka hipotesis ditolak sedangkan jika Asymp. Sig > 0,05 maka hipotesis diterima. Berdasarkan output uji stasistik diketahui Asymp.Sig (2-tailed) bernilai $0,000<0,05$, maka dapat disimpulkan bahwa hipotesis ditolak artinya ada perbedaan antara hasil keanekaragaman stasiun 1 dan stasiun 2 , yang artinya ada pengaruh yang membedakan hasil stasiun 1 dan 2 .

\section{Indeks Keseragaman (E)}

Berdasarkan hasil dari pada perhitungan indeks keseragaman pada Tabel 4.8 di bawah Tabel 4. Indeks Keseragaman Teripang pada Tiap Stasiun Pengamatan menyatakan bahwa penyebaran dari jumlah individu jenis pada stasiun 1 kelas ke-3 memiliki nilai indeks keseragaman 0,785 dan pada kelas ke-4 memiliki nilai indeks keseragaman sebesar 0,685 , hal tersebut menyatakan bahwa pada stasiun 1 dengan kelas penutupan lamun berbeda termasuk dalam kriteria keseragaman tinggi $\left(E^{\prime}>0,6\right)$, sedangkan pada stasiun 2 dengan kelas penutupan lamun ke-2 sebesar 0,918 dan ke-3 sebesar 0,994, hal tersebut menyatakan bahwa pada stasiun 2 dengan kelas penutupan lamun berbeda termasuk dalam kriteria indeks keseragaman tinggi $\left(E^{\prime}>0,6\right)$. Berdasarkan data perhitungan indeks keseragaman yang telah di sesuaikan dengan kriteria di bawah menyatakan bahwa di perairan Pulau Sapudi yang lebih tepatnya pada kedua stasiun dengan kelas penutupan lamun yang berbeda tersebut memiliki penyebaran teripang dengan indeks keseragaman yang tinggi. Menurut Krebs (1978) apabila nilai indeks keseragaman tinggi (mendekati 1) menunjukkan bahwa kandungan setiap jenis mengalami perbedaan, dan Odum (1971) menjelaskan semakin besar dari nilai E, maka tingkat keseragaman dari populasi teripang semakin besar dan penyebaran individu dari tiap spesiesnya merata atau tidak ada spesies yang mendominasi.

\begin{tabular}{lll}
\hline Stasiun & Kelas & Kes \\
\hline 1 & 3 & 0 \\
\hline 2 & 4 & 0 \\
\hline Keterangan : & 2 & 0 \\
\hline $\begin{array}{l}\text { Nilai indeks } \\
\text { keseragaman (E') }\end{array}$ & 3 \\
\hline $\mathrm{E}<0,4$ & $\begin{array}{l}\text { Kkiteria } \\
\text { kondistem berada dalam } \\
\text { keseragaman rendah. } \\
\text { Ekosistem berada dalam } \\
\text { kondisi kurang stabil dan } \\
\text { keseragaman sedang. } \\
\text { Ekosistem berada dalam } \\
\text { kondisi stabil dan } \\
\text { keseragaman tinggi. }\end{array}$ \\
\hline$E>0,4 \mathrm{E}>0,6$ & yang diperol kemudian
\end{tabular}

Nilai keseragaman yang diperoleh kemudian dilakukan pengujian hipotesis dengan SPSS untuk membandingkan keseragaman teripang stasiun 1 dan stasiun 2. Uji statistik yang dilakukan terlebih dahulu dengan menggunakan uji normalitas. Hasil uji normalitas perhitugan signifikan: Test Kolmogrov - Smirnov $=0,000<0,05$ (data nilai tidak berdistribusi normal) dan hasil Shapiro - Wilk $=0,001<0,05$ (data nilai tidak Keseragaman (E) Keterangan

0,785 Tinggi

$0,685 \quad$ Tinggi

$0,918 \quad$ Tingg

$0,994 \quad$ Tinggi

berdistribusi normal). Karena data tidak berditsribusi normal maka pengujian yang di gunakan untuk pengambilan hipotesis yaitu menggunakan perhitungan non parametrik yaitu dengan uji Mann-Whitney sebagai pengganti Uji T. Pengambilan keputusan uji Mann-Whitney yaitu jika nilai Asymp.Sig < 0,05 maka hipotesis ditolak sedangkan jika Asymp. Sig > 0,05 maka hipotesis diterima. Berdasarkan output uji stasistik diketahui Asymp.Sig (2-tailed) bernilai 0,625 > 0,05, maka dapat disimpulkan bahwa hipotesis diterima artinya tidak ada perbedaan antara hasil keseragaman stasiun 1 dan stasiun 2 , yang artinya tidak ada pengaruh yang membedakan hasil stasiun 1 dan 2.

\section{Indeks Dominansi (D)}

Berdasarkan hasil perhitungan indeks dominansi teripang pada setiap stasiun mendapatkan hasil yang berbeda yaitu pada 
Akrama dan Insafitri, Struktur Komunitas Teripang (Holuthuroidea)

stasiun 1 dengan kelas persen penutupan lamun ke-3 diperoleh hasil Indeks Dominansi rata-rata sebesar 0,268 dan kelas ke-4 sebesar 0,081 sedangkan pada stasiun 2 dengan kelas persen penutupan lamun ke-2 diperoleh hasil Indeks Dominansi rata-rata sebesar 0,555 kelas ke-3 sebesar 0,504. Hal tersebut menunjukkan bahwa pada kedua stasiun dengan kelas persen penutupan lamun yang berbeda tersebut tergolong dalam keadaan indeks dominansi rendah. Menurut
Odum (1963) sebaran jenis dari suatu organisme berkaitan erat dengan dominansi jenis, apabila semakin tinggi nilai dari Indeks Dominansi (D), maka akan semakin tinggi pula kecendrungan adanya jenis yang mendominasi disuatu stasiun. Berdasrkan hasil data Indeks Dominansi yang diperoleh dari kedua stasiun tersebut menunjukkan bahwa tidak adanya spesies atau jenis teripang yang mendominasi dikedua stasiun tersebut.

Tabel 5. Indeks Dominansi Teripang pada Tiap Stasiun Pengamatan

\begin{tabular}{|c|c|c|}
\hline Stasiun & Kelas & Dominansi (D) \\
\hline \multirow[t]{2}{*}{1} & 3 & Rendah \\
\hline & 4 & Rendah \\
\hline \multirow[t]{2}{*}{2} & 2 & Rendah \\
\hline & 3 & Rendah \\
\hline \multicolumn{2}{|l|}{ Keterangan: } & yaitu dengan uji Mann-Whitney sebagai \\
\hline $\begin{array}{l}\text { Nilai indeks } \\
\text { dominansi (D) }\end{array}$ & Kriteria & $\begin{array}{l}\text { pengganti Uji T. Pengambilan keputusan uji } \\
\text { Mann-Whitney yaitu jika nilai Asymp.Sig < }\end{array}$ \\
\hline $0<\mathrm{D}<0,5$ & $\begin{array}{l}\text { Dominansi rendah (tidak } \\
\text { terdapat spesies yang secara } \\
\text { ekstrim mendominasi spesies } \\
\text { lainnya), kondisi lingkungan } \\
\text { stabil, dan tidak terjadi } \\
\text { tekanan ekologis terhadap } \\
\text { biota di stasiun tersebut. } \\
\text { Dominansi sedang dan }\end{array}$ & $\begin{array}{l}0,05 \text { maka hipotesis ditolak sedangkan jika } \\
\text { Asymp. Sig > 0,05 maka hipotesis diterima. } \\
\text { Berdasarkan output uji stasistik diketahui } \\
\text { Asymp.Sig ( } 2 \text {-tailed) bernilai } 0,712>0,05 \text {, } \\
\text { maka dapat disimpulkan bahwa hipotesis } \\
\text { diterima artinya tidak ada perbedaan antara } \\
\text { hasil dominasi stasiun } 1 \text { dan stasiun } 2 \text {, yang }\end{array}$ \\
\hline $0,5<D<0,75$ & $\begin{array}{l}\text { kondisi lingkungan cukup } \\
\text { stabil. }\end{array}$ & $\begin{array}{l}\text { artinya tidak ada pengaruh yang membedakan } \\
\text { hasil stasiun } 1 \text { dan } 2 \text {. }\end{array}$ \\
\hline
\end{tabular}

\section{Persen Penutupan Lamun}

Berdasarkan hasil penelitian yang dilakukan pada kedua stasiun dengan tiga titik setiap stasiunnya. Pengamatan dilakukan dari awal di temukan lamun sampai tidak di temukan lamun secara acak atau random menurut kelas penutupan lamunnya. Hasil pada stasiun 1 diperoleh 2 kelas persen penutupan lamun yaitu kelas persen penutupan lamun ke-3 dengan nilai rata-rata sebesar $22,47 \%$ dan pada kelas persen penutupan lamun ke-4 sebesar $26,894 \%$. Pada stasiun kedua juga diperoleh 2 kelas persen penutupan lamun yaitu kelas persen penutupan lamun ke-2 dengan nilai rata-rata sebesar $11,84 \%$ dan kelas persen penutupan ke-3 dengan nilai rata-rata sebesar $15,316 \%$. Pernyataan tersebut dapat di lihat pada Tabel 4.6.

Tabel 6. Persen Penutupan Lamun

\begin{tabular}{llll}
\hline Stasiun & Kelas & Persen Penutupan Lamun (\%) & $\begin{array}{l}\text { Baku Mutu } \\
\text { (English et al 1994) }\end{array}$ \\
\hline 1 & 3 & 22,47 & $12,5-25$ \\
\hline 2 & 4 & 26,894 & $25-50$ \\
\hline & 2 & 11,84 & $6,25-12,5$ \\
\hline
\end{tabular}

Nilai persen penutupan lamun yang diperoleh kemudian dilakukan pengujian hipotesis dengan SPSS untuk membandingkan persen penutupan lamun stasiun 1 dan stasiun 2 . Uji 
Juvenil, 1(2), 180-188, (2020)

statistik yang dilakukan terlebih dahulu dengan menggunakan uji normalitas. Hasil uji normalitas perhitugan signifikan: Test Kolmogrov - Smirnov $=0,000<0,05$ (data nilai tidak berdistribusi normal) dan hasil Shapiro - Wilk $=0,000<0,05$ (data nilai tidak berdistribus normal). Karena data tidak berdistribusi normal maka pengujian yang di gunakan untuk pengambilan hipotesis yaitu menggunakan perhitungan non parametrik yaitu dengan Mann-Whitney sebagai pengganti Uji T. Pengambilan keputusan uji Mann-Whitney yaitu jika nilai Asymp.Sig < 0,05 maka hipotesis ditolak sedangkan jika Asymp. Sig > 0,05 maka hipotesis diterima.

Tabel 7. Kualitas Perairan Stasiun Penelitian
Berdasarkan output uji stasistik diketahui Asymp.Sig (2-tailed) bernilai $0,000<0,05$, maka dapat disimpulkan bahwa hipotesis diterima artinya ada perbedaan antara hasil persen penutupan lamun stasiun 1 dan stasiun 2 , yang artinya ada pengaruh yang membedakan hasil stasiun 1 dan 2.

\section{Kualitas Perairan}

Pengukuran parameter kualitas perairan diperoleh dari data primer yang dilakukan secara langsung di pulau Sapudi kabupaten Sumenep. Adapun hasil data primer kualitas perairan yang diperoleh dari stasiun penelitian di tampilkan pada Tabel 7 .

\begin{tabular}{llllll}
\hline \multirow{2}{*}{ No } & \multirow{2}{*}{ Parameter } & \multicolumn{2}{c}{ Hasil Pengukuran } & \multicolumn{1}{c}{ Baku Mutu } & Keterangan \\
\cline { 3 - 6 } & Stasiun 1 & Stasiun 2 & & \\
\hline 1 & Suhu $\left({ }^{\circ} \mathrm{C}\right)$ & $30{ }^{\circ} \mathrm{C}$ & $32{ }^{\circ} \mathrm{C}$ & $22-32{ }^{\circ} \mathrm{C}$ Satria $(2014)$ & Sesuai \\
\hline 2 & Salinitas $(\% \circ)$ & $31 \% \circ$ & $30 \% 0$ & $30-37 \%$ Martoyo et al., (2006) & Sesuai \\
\hline 3 & DO $(\mathrm{mg} / \mathrm{l})$ & $7,5 \mathrm{mg} / \mathrm{l}$ & $6,24 \mathrm{mg} / \mathrm{l}$ & $4-8 \mathrm{mg} / \mathrm{l}$ Karayawati et al., (2004) & Sesuai \\
\hline 4 & $\mathrm{Ph}$ & 7 & 7 & $7-8,5$ Satria $(2014)$ & Sesuai \\
\hline 5 & Kecerahan $(\mathrm{m})$ & $93 \mathrm{~cm}$ & $137 \mathrm{~cm}$ & $0,50-1,50 \mathrm{~m}$ Rustam $(2006)$ & Sesuai \\
\hline 6 & Arus & $0,17 \mathrm{~m} / \mathrm{s}$ & $0,12 \mathrm{~m} / \mathrm{s}$ & $<0,2 \mathrm{~m} / \mathrm{s}$ Oktamalia et al $(2013)$ & Sesuai \\
\hline
\end{tabular}

Substrat

Berdasarkan hasil penelitian substrat di lapang diperoleh data analisis substrat yang dapat

Tabel 8. Data Analisis Substrat Stasiun Penelitian dilihat pada Tabel 4.8. sampel substrat yang dianalisa tiap stasiun terdapat tiga titik pengambilan sampel.

\begin{tabular}{lllll}
\hline STASIUN 1 & Fraksi Sedimen (\%) & & \multirow{2}{*}{ Tipe Sedimen } \\
\cline { 1 - 4 } & Pasir & lanau & Lempung & \\
\hline Titik 1 & 99,71 & 0,08 & 0,19 & Pasir \\
\hline Titik 2 & 97,55 & 2,22 & 0,22 & Pasir \\
\hline Titik 3 & 93,53 & 2,66 & 3,79 & Pasir \\
\hline STASIUN 2 & & & \\
\hline Titik 1 & 99,4 & 0,42 & 0,17 & Pasir \\
\hline Titik 2 & 96,13 & 3,63 & 0,22 & Pasir \\
\hline Titik 3 & 99,67 & 0,16 & 0,15 & Pasir \\
\hline $\begin{array}{l}\text { Berdasarkan data hasil dari penentuan jenis } \\
\text { subtrat menggunakan sieve shaker dengan 18 }\end{array}$ & \multicolumn{2}{c}{ Kesimpulan } &
\end{tabular}

sampel substrat yang telah dilakukan analisis kering menunjukkan bahwa hasil substrat dari stasiun 1 dan stasiun 2 diperoleh hasil subtrat pasir. Hasil tersebut menunjukkan bahwa subtrat pada lokasi penelitian baik untuk kehidupan teripang, karena Menurut Bakus (1973) teripang merupakan biota laut yang menempati substrat berpasir, karena teripang pada umumnya memiliki sifat deposit feeder yang memakan apa saja di dasar perairan.

Kepadatan teripang pada stasiun 1 lebih tinggi dibandingkan stasiun 2. Hasil uji MannWhitney kepadatan teripang pada stasiun 1 dan 2 memiliki perbedaan yang signifikan. Indeks keanekaragaman pada stasiun penelitian diperoleh kriteria yang berbeda yaitu stasiun 1 sedang dan pada stasiun 2 rendah. Hasil uji Mann-Whitney keanekaragaman teripang pada stasiun 1 dan 2 memiliki perbedaan yang signifikan. Indeks keseragaman pada stasiun penelitian 
Akrama dan Insafitri, Struktur Komunitas Teripang (Holuthuroidea)

termasuk kriteria yang tinggi. Hasil uji MannWhitney keseragaman teripang pada stasiun 1 dan 2 tidak memiliki perbedaan yang signifikan. Indeks dominasi pada stasiun penelitian pada stasiun 1 tergolong rendah dan stasiun 2 tergolong sedang. Hasil uji Mann-Whitney dominasi teripang pada stasiun 1 dan 2 memiliki perbedaan yang signifikan. Semakin tinggi kelas penutupan lamun, maka semakin tinggi kepadatan teripangnya. Hasil uji Mann-Whitney persen penutupan lamun pada stasiun 1 dan 2 memiliki perbedaan yang signifikan. Hasil pengukuran kualitas perairan yang telah dilakukan pada stasiun penelitian diperoleh hasil yang sesuai dengan baku mutu teripang.

\section{DAFTAR PUSTAKA}

Bakus, G.J. (1973). The Biologi and Ecology of Tropical Holothutians. Academic Press. New York.

Karyawati, T., Hartati, R., \& Rudiana, E. (2004). Konsumsi Oksigen Teripang Hitam (Holothuria atra) pada Sistem Statis dan Sistem Dinamis. ILMU KELAUTAN: Indonesian Journal of Marine Sciences, 9(3), 169-173.

Krebs, C. J. (1978). Ecology: The experimental analysis of distribution nad abundance (No. 574.5 K7 1978.).

Martoyo, J., Aji. N., dan T. Winanto. (2006). Budidaya Teripang. Penebar Swadaya. Jakarta.

Muharram, N. (2006). Struktur Komunitas Perifiton dan Fitoplankton di Bagian Hulu Sungai Ciliwung, Jawa Barat. Skripsi. Departemen Sumberdaya Perairan. Fakultas Perikanan dan IImu Kelautan. Institut Pertanian Bogor.

Odum, E.P. (1963). Ecology. The University of Georgia, USA: 152 pp.

Odum, E. P. (1971). Fundamental of Ecology. 3rd Eds. W. B. Saunders Company. Philadelphia: 574 p.

Oktamalia, O., Purnama, D., \& Hartono, D. (2016). Studi Jenis dan Kelimpahan Teripang (Holothuroidea) di Ekosistem Padang Lamun Perairan Desa Kahyapu Pulau Enggano. Jurnal Enggano, 1(1), 9-17.

Rustam. (2006). Budidaya Teripang. Coremap Tahap II Kabupaten Selayar. Yayasan Mattirotasi.

Satria, G. G. A., Sulardiono, B., \& Purwanti, F. (2014). Kelimpahan Jenis Teripang Di Perairan Terbuka Dan Perairan Tertutup Pulau Panjang Jepara, Jawa Tengah. Management of Aquatic Resources Journal, 3(1), 108-115.
Supono, A. U. (2010). Struktur komunitas ekinodermata di padang lamun Perairan Kema, Sulawesi Utara. Oseanology dan Limnologi Indonesia, 36(3), 329-341.

Suryaningrum, T. D. (2008). Teripang: potensinya sebagai bahan nutraceutical dan teknologi pengolahannya. Squalen, 3(2), 63-69.

Winda, D.M. (2013). Struktur Dan Sebaran Komunitas Bulu Babi (Echinoidea) Di Habitat Lamun Pulau Sapudi, Kabupaten Sumenep, Madura. Skripsi. Institut Pertanian Bogor. 